Article

\title{
Enhanced Cash Flow Valuation in Real Estate Management by Integrating Innovative Materials and Risk Assessment
}

\author{
Patrick Bergmann ${ }^{1, *}$, Endre Kamarás ${ }^{2}$, Werner Gleißner ${ }^{2}$ and Edeltraud Guenther ${ }^{1,3, *}$ \\ 1 Faculty of Business and Economics, Technische Universität Dresden, Münchner Platz 1/3, \\ 01187 Dresden, Germany \\ 2 FutureValue Group AG, Obere Gärten 18, 70771 Leinfelden-Echterdingen, Germany; \\ e.kamaras@futurevalue.de (E.K.); w.gleissner@futurevalue.de (W.G.) \\ 3 Institute for Integrated Management of Material Fluxes and of Resources (UNU-FLORES), \\ United Nations University, Ammonstrasse 74, 01067 Dresden, Germany \\ * Correspondence: patrick.ilg@tu-dresden.de (P.B.); ema@tu-dresden.de (E.G.); Tel.: +49-176-83090945 (P.B.); \\ +49-351-46334313 (E.G.)
}

Received: 30 December 2019; Accepted: 10 March 2020; Published: 12 March 2020

check for updates

\begin{abstract}
Environmental criteria have become a critical issue for the evaluation of projects and products, particularly for businesses with extensive life cycles. Sustainability criteria and project risk management are underexplored in real estate development, and thus endanger business survival. The aim of this article is to improve the understanding of uncertainties in the real estate industry by using a stochastic risk assessment approach and to broaden the risk assessment methodology. Thus, this article investigates the importance of material selection regarding external and project risk for real estate development. Aside from conventional projects, risks are analyzed for projects with high-quality materials (HQMs) that are characterized by environmental benefits. In following a mixed method approach, we began by conducting interviews with developers about the most important risks, and later incorporating these factors into a stochastic cash-flow model. Finally, we illustrated our findings in a case study. Overall, the highest risks were shown from resource prices and changing regulations, while the rankings of the two materials differ slightly; HQMs rank higher on the created risk index than conventional materials. The cash-flow model shows that conventional materials perform slightly better than HQMs, although uncertainties within the calculations are similar. The article contributes to risk management and decision-making for real estate projects by providing insights into the discussion and analysis of the financial performance of sustainable construction material and design that might be crucial for disruptive innovations. We present a model that integrates environmental and long-term effects in the cash-flow evaluation of real estate projects, thereby increasing managerial flexibility.
\end{abstract}

Keywords: risk analysis; economic-environmental sustainability evaluation; material selection; decision making; green construction; real estate development; cash flow model

\section{Introduction}

An increase in the combination of government regulation, stronger public awareness, and consumer pressures is making businesses more cautious about the impact of their products on the environment. As a result, environmental management is growing in importance [1,2]; businesses cannot simply neglect environmental issues if they intend to survive in the current global market [3]. Green product design has especially gained in prominence, as it significantly influences the cost of disassembly, maintenance and repair, remanufacturing and recycling [4], and the environmental 
awareness of a company and its products is becoming progressively valued as a driver for the successful market penetration of new materials as a component of disruptive innovations [5].

Real estate is a flagship industry regarding these aspects, as its associated projects are characterized by very long life cycles [6], large investments [7] which are often irreversible, enormous greenhouse gas emissions, and significant depletion of natural resources and energy [8,9]. A building's impact on the environment must be classified as being low in order for it to be certified. (e.g., BREEAM, LEED, DGNB) $[10,11]$. As most real estate clients and investors require these certifications [12], the eligibility of a company to meet the associated criteria is a prerequisite for business continuity. Moreover, according to a survey of the World Business Council for Sustainable Development, $89 \%$ of practitioners agree that sustainability risks could lead to a significant impact on business [13]. In order to meet these challenges, one of the main goals of the real estate industry is to adapt designs and material selection to reduce the detrimental impact on the environment [14].

Although many companies already recognize the need for risk assessment, few invest time and resources to mitigate or predict certain risks $[15,16]$ that might affect the implementation of real estate projects and their success, such as changing the design of buildings. Regardless of environmental-related issues, the real estate industry must mitigate several risks to guarantee the survival of the industry $[17,18]$ : first, real estate projects must consider project-related risks stemming from random fluctuations in labor productivity, among others [19]. Second, a large proportion of real estate projects are implemented by consortia of small and medium-sized enterprises with limited capital resources [20]. Third, real estate projects depend on revenue fluctuations due to public bidding and high-demand volatility [21].

The real estate development industry amasses and applies its financial and physical resources to construct newly built spaces, with many businesses being exposed to most of these risks in the very early stages of project management [21]. The overarching purpose of a developer is the sale of the built assets; as with any participant in business, developers aim to increase profit, while reducing uncertainty. A higher level of uncertainty potentially leads to higher deviations from projections, which requires more equity and results in higher capital costs (discount rates) to a subsequently lower fundamental value [20]. Moreover, investors and clients (e.g., housing associations), in an attempt to avoid risk, require a transparent line of communication regarding uncertainties and are often willing to pay more for lower-risk assets [21].

One option of dealing with the environmental requirements and uncertainty that is often applied in the current market is to use high-quality materials (HQMs). In this article, HQMs are characterized by longevity, low-energy consumption, a reduction in material diversity, and environmentally compatible disposal. Examples include self-healing concrete, light-diverting louvers, carbon reinforced concrete, structural insulated panels, or wood-based insulating foam. These materials allow higher market prices and lead to lower maintenance costs.

In line with prior research [2,22,23], we argue for extending classical risk assessment. A similar approach has been put forward by Fregonara, Ferrando and Pattono [4], whose research focused on the cost side of real estate projects and on environmental impacts, e.g., energy and $\mathrm{CO}_{2}$. Based on this research, we propose broadening the idea of risk assessment by categorizing the risks according to empirical information gathered by expert interviews, and then applying this assessment to a cash-flow model, considered to be state-of-the-art methodology in real estate valuation [21].

The aim of this article is twofold: first, to improve the understanding of uncertainties in the real estate industry by using a stochastic risk assessment approach, which will enable us to further apply these findings to risk management. In this context, stochastic means that the model is not based on the average figures of historic data, but rather involves probability distributions to estimate uncertain parameters. Secondly, we aim to broaden the risk assessment methodology by integrating environmental aspects and new materials. The interaction of market price, uncertainty, and environmental impacts in real estate projects is approached in three research questions: 
1. Which risks must be taken into consideration when comparing conventional and high-quality materials?

2. What does a risk assessment approach that integrates these risks look like?

3. How do these risks influence project cash-flow?

We investigate this multi-layered and interdisciplinary topic with a mixed-method, triple-staged approach. First, to identify project-related risks, a literature review of risk management in real estate projects is performed. Afterwards, risks are evaluated with real estate developers and their customers then ranked accordingly. Alternative projects using HQMs are studied, alongside conventional projects. Second, the ranked risks are incorporated in a stochastic model. We initially model precise project planning by comparing the estimated costs and retail prices. As proper risk management is only possible if the risk exposure, both ex post and ex ante, is known, and due to imperfect real estate markets, this article suggests, similar to Szumilo et al. [24], a new approach to risk assessment by using a stochastic approach to predict future uncertainty, rather than concentrating on historical values. Third, the model is applied to an office building in Germany, in a middle-sized city, based on real data from the project developers. This last stage combines the two previous stages and shows the effects of conventional and HQM on the cash-flow. Moreover, it illustrates the impacts of different materials on uncertainties inherent to economic forecasts.

Our results and conclusion further enhance the scientific discussion of risk assessment in real estate projects by addressing ecological aspects in a stochastic value evaluation. A novelty is the combination of qualitative and quantitative methods for real estate appraisal: qualitatively discussed and ranked risks are included in a quantitative cash-flow analysis to demonstrate the impact of material selection. Moreover, we present the most important material-related risks experienced by practitioners in the German real estate market, and, as a result, we reveal insights on the impacts of individual risk factors on the overall cash flow.

The stochastic model contributes to improved risk assessment in the real estate industry, which so far has been dominated by intuition and rules-of-thumb $[25,26]$. Apart from the independence shown in outdated data, the model minimizes the risk of construction projects and, hence, fosters the business of many SMEs. Finally, the results identify the most important risks in real estate development, which should then be mitigated by practitioners.

In the next section, the theory and literature in relation to risk assessment and developments in the real estate industry are reviewed, after which the applied method is illustrated. The following section presents the results, including the most important risks and the stochastic model. Finally, the findings are discussed, and conclusions are drawn.

\section{Literature Review and Theoretical Background}

The scientific discussion shows that for a risk-adequate assessment of investments in real estate or infrastructure, uncertain cash flows of assets must be examined.

\subsection{Uncertainty and the Importance of Risk Assessment}

The identification and assessment of risk and uncertainty within the scope of property valuations is currently one of the key concerns in contemporary valuation literature $[27,28]$. Uncertainty is defined as "the state of being uncertain; doubt; hesitancy" and, as a result, neither loss nor gain is necessarily associated with uncertainty; it is simply missing certainty [29]. Risk, in contrast, is usually defined as the volatility, quantified through the variance or standard deviation of its returns [27]. The application of risk analysis in the construction industry is not as common as other sectors, such as insurance or finance [30,31]. Still, risk analysis is important as it provides the decision maker with the opportunity to take mitigating action to decrease exposure to risk, or to make decisions about accepting risk [18].

Thus, in 2012, the European Group of Valuers' Associations [32] provided a systematic classification of risks into: a) market risks (change of investment policies), b) property-related risks (location risk, 
construction-related property risk, tenants and leases risk), c) fiscal and legal risks (political changes, change in regulation), and d) financial risks. In contrast to this article, D'Alpaos and Canesi (2014) assessed the risk in real estate investments in times of global crisis. After building an evaluation model to address risk and uncertainty in property investment decisions, they concluded that the net present value is not the best/only information to base decisions on in times of crisis. Mao and $\mathrm{Wu}$ [33] proposed a different model: a fuzzy real option evaluation, in order to choose the right investment project. They stressed the importance of risk assessment, especially during normal economic growth and crisis. A topic of growing importance was investigated by Bai et al. [34], who applied a fuzzy evaluation model on public private partnership (PPP) projects. Chan et al. [35] followed a similar approach and identified and ranked the key risk factors associated with target cost contracts, and came up with a list of 34 risks which form, among others, the basis for this survey. Finally, Fregonara et al. [4] applied a stochastic simulation to a multifunctional building glass façade project to support decision-making in the design stage. Their conjoint "economic-environmental indicator" is very close to what we apply in the current article, and thus acts as conversant [36].

\subsection{Rising Trend of Sustainability Criteria}

In the last decade, sustainable aspects and their impact on real estate projects have become more important [37-39]. Green materials and products have been applied by architects, developers, and construction companies [40], with hallmarks including extensive life cycles [6], large and mainly irreversible investments [7], and the extensive use of natural resources and energy [8,9] to direct the focus of investors, clients, and the government toward sustainability issues [38]. Thus, it can be considered that the higher the ranking in a sustainable building certification, the lower the risk for a certain project. Among others, Gluch and Baumann [25] called for the further development of tools to integrate environmental and micro-economic dimensions into risk analysis. Environmental impacts on real estate projects have become more important, as they affect the vital investor-and-client-required [23] certification of projects. The experience of international certification systems shows that sustainable buildings have many advantages in comparison with conventional buildings [41]: they generate higher real estate value and improve marketability, minimize risk, take account of user requirements, create comparability, and, last but not least, serve the environment. A study from the University of Cambridge, for example, found that real estate investment trusts with higher sustainability scores tend to show higher returns on equity, higher returns on assets, and stronger risk-adjusted stock performance [42].

These findings are supported by Eichholtz et al. [43], who proved that if the amount of properties certified by Leadership in Energy and Environmental Design (LEED) in the portfolio increases by $1 \%$, the market beta of REITs decreases by 0.14 . Future environmental impacts will influence risks associated with the real estate industry, manifesting in regulation, financing, and demand by the public or commercial clients.

\subsection{The Procedure of a Stochastic Risk Assessment}

As with any project undergoing a risk-based assessment, it is advisable to value a real estate project with a (quantitative and qualitative) risk analysis. The first phase of risk assessment involves the systematic and structured identification of potential risks. Analyzing work processes, workshops, benchmarks, or checklists are examples of this identification process [44], and by systemically studying the most important success potentials and the potential threats to the project or company, strategic risks can be identified. Finally, certain types of risk are best determined through a collection of the "complex relationships inherent in the situation" [44] and following critical discussions in a workshop. For operational risks related to the value chain, work processes are described and analyzed step-by-step to determine which risks could cause a deviation from the planned process sequence; the significant risks are subsequently summarized in a risk inventory. 
Regarding the imperfection of real estate markets, the application of historical data to estimate risk-adjusted discount rates might lead to inaccurate predictions $[45,46]$, particularly less diversifiable assets (such as real assets), which are prone to other risk factors. It is for this reason that a stochastic model is preferable as a sophisticated risk management strategy. We apply an appropriate (mathematical) distribution function to deal with the assessed risks, which are quantified according to probability of occurrence and potential extent of harm; this is known as a binomial or digital distribution. Certain risks, such as deviations in maintenance costs or interest charges, reach varying levels of risk with different probabilities, and are better described using other distribution functions such as triangular distribution with minimum value, highest probability value and maximum value, or normal distribution with expected value and standard deviation.

When assessing risks, considering the actual impact of risk that occurred in the past, or in other projects, aids in benchmarking values from the industry or damage scenarios. This is useful for comparing all forms of risk with each other in terms of significance, a consistent risk measure, e.g., value at risk.

Consequently, the total level of risk (and therefore, the extent of the threat to the company) is calculated in a "risk aggregation". A risk inventory only allows a company to derive which risks present a threat to the company's earnings or existence. Risk aggregation enables the analysis of the combined effect of multiple individual forms of risk, and involves contextualizing the assessed forms of risk in terms of planning, and then demonstrating which form of risk threatens deviations at certain points in planning. As forecasted cash-flow distributions are highly dependent on the assumptions that determine the midpoints, either sensitivity analysis or scenario planning is demanded by several authors [47]. Moreover, accessible historical default rates and other information have shown to be either unrepresentative or non-existent in the case of real estate rating [24]. Thus, expanding a model with a Monte Carlo simulation (MCS) outperforms sensitivity analysis, as various values for the assumptions are calculated stochastically, basing the calculation on a much broader and more objective sample. With the help of a risk simulation process, many potential future risk-related scenarios can be identified and analyzed.

\section{Materials and Methods}

As mentioned before, the methodological approach is three-fold (see Figure 1). We carried out a review of the literature to identify the relevant risks connected to real estate projects. The search string "risk OR uncertainty AND building OR "real estate" OR "property develop*" OR construction" was applied to the scientific databases EBSCOhost, Emerald, ScienceDirect, SpringerLink, and Wiley.

Afterwards, the results were checked with Google Scholar, with all search terms being applied to title, abstract, and keywords in the bibliographic databases. Cross-references that included appropriate articles from the studies identified in the search process completed our empirical basis. Relevant literature in English was identified by applying previously determined criteria for the inclusion in a practical screening. In total, 3501 articles were identified, of which 362 were double entries. For the initial screening of titles and abstracts, only articles showing a direct link to risk and real estate projects were considered. This first screening resulted in 364 relevant articles. In the next screening of the article collection, we excluded 302 articles due to an absent connection to our research questions. As a result, 62 articles were identified for the literature review. A coding scheme was then applied to all identified articles; a qualitative data analysis software program called MaxQDA was used to execute the coding. 


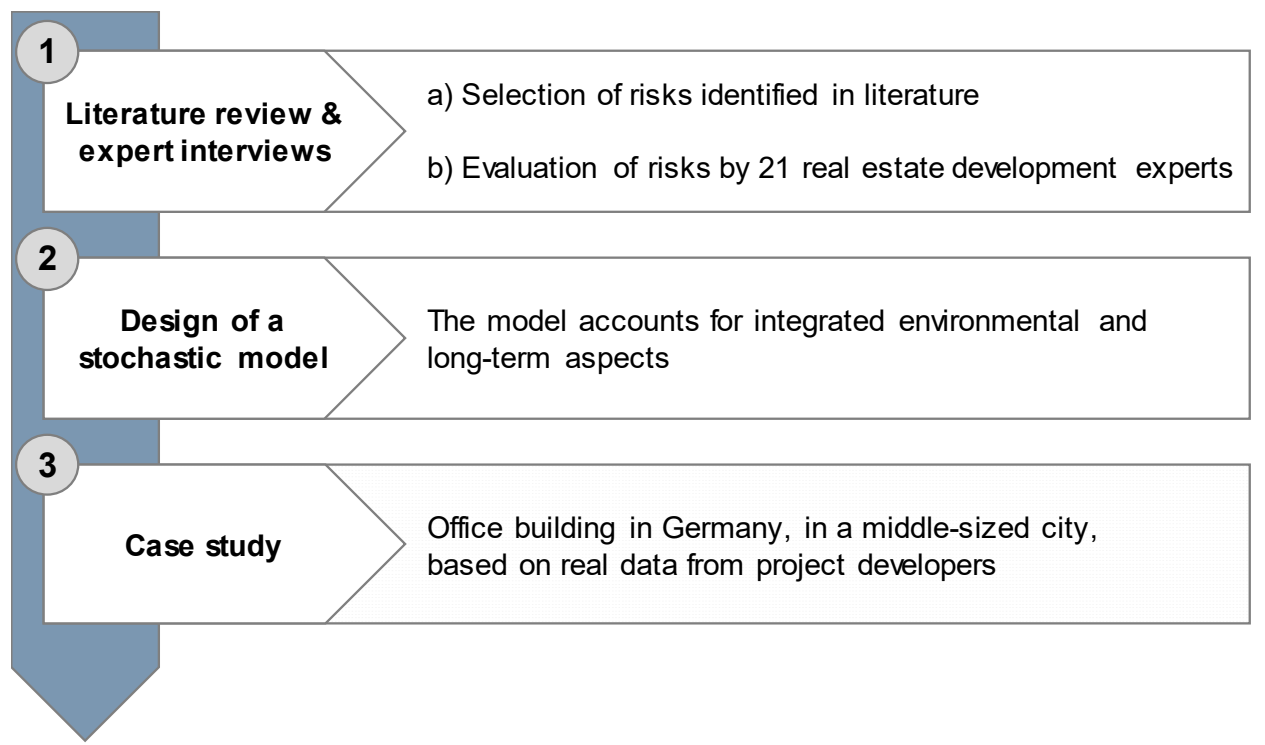

Figure 1. Overview of the applied mixed method three-stage approach.

As very little information on new concepts regarding risk assessments for environmental impacts in risk assessments for corporate real estate management exists, we verified the identified risks in the literature through expert interviews, similar to Högberg et al. [48]. Interviewees were chosen by theoretical sampling $[49,50]$, with interview requests being sent to the ten largest real estate developers (according to revenue) and leading consulting companies in Germany. After the companies were selected, contact persons were identified via their website or following telephone calls. In total, we contacted 38 experts throughout Germany. Afterwards, a short project description and a list of all risks were sent via e-mail to the interviewees. Finally, the interviews were conducted from October to December 2016 via telephone or in person. The interviews are part of a previous research project of the Chair of Sustainability Management and Accounting at TU Dresden and built the base for the risk index. The interviews were based on a set of interview guidelines, which had been previously was pre-tested with colleagues and external experts, and lasted between 30 and 50 minutes. The content of the interviews was based upon the basis of the 42 risks identified in the literature (see Appendix A). These risks had to be ranked on a scale from 0 (not relevant) to 10 (very relevant), with importance being defined as the financial net- perceived impact of a risk on the project. Theoretical saturation [50,51] was reached after 18 interviews, and we discontinued further contacts with the remaining experts as no new information was being gathered. The findings of the practitioners were backed up by three researchers in the field of real estate assessment. An overview of the interviewees is provided in Table 1.

The authors analyzed the audio recordings of the interviews after they were transcribed. A 'risk significance index score' was built according to the average score of each risk, multiplied by the frequency it was mentioned and divided by the number of interviewees. The top nine ranked risks were chosen to be included in the stochastic model, as a gap in the absolute importance value was visible after nine. Three additional risks were added in both material groups, as they ranked highly in the respective control group (for an overview of all risks and the score of each individual risk, see Appendix A). 
Table 1. Overview of experts.

\begin{tabular}{|c|c|c|c|c|c|}
\hline No & Branch & Company & Position & $\begin{array}{l}\text { Experience } \\
\text { (years) }\end{array}$ & Academia \\
\hline \#1 & Industry & Project development & Branch Manager & $<10$ & Economist \\
\hline \#2 & Industry & Construction & Founder & n.a. & Architect \\
\hline \#3 & Industry & Real estate developer & Managing Director & n.a. & n.a. \\
\hline$\# 4$ & Industry & Real estate developer & Technical Director & $<15$ & Civil Engineer \\
\hline \#5 & Industry & Real estate developer & Head of Development & $<15$ & Architect \\
\hline \#6 & Industry & Real estate developer & Head of Development & $<5$ & Industrial engineer \\
\hline \#7 & Industry & Engineering & Managing Director & $<30$ & Industrial engineer \\
\hline$\# 8$ & Industry & Real estate developer & $\begin{array}{l}\text { Head Technical } \\
\text { Controlling }\end{array}$ & $<30$ & n.a. \\
\hline \#9 & Industry & Real estate developer & Head of Development & $<15$ & Industrial engineer \\
\hline$\# 10$ & Industry & Real estate developer & Project manager & n.a. & n.a. \\
\hline \#11 & Industry & Real estate developer & Head of Development & $<25$ & Architect \\
\hline$\# 12$ & Industry & Real estate developer & Managing Director & $<10$ & n.a. \\
\hline \#13 & Industry & Project management & Project manager & $<30$ & Architect \\
\hline \#14 & Consultancy & Real estate advisory & Manager & $<5$ & Industrial engineer \\
\hline \#15 & Consultancy & Real estate advisory & Partner & $<30$ & Lawyer \\
\hline \#16 & Consultancy & Real estate advisory & Partner & $<25$ & $\begin{array}{c}\text { Business } \\
\text { administration }\end{array}$ \\
\hline \#17 & Consultancy & Real estate advisory & Partner & $<25$ & Civil Engineer \\
\hline \#18 & Consultancy & Real estate advisory & Manager & $<15$ & $\begin{array}{c}\text { Business } \\
\text { administration }\end{array}$ \\
\hline \#19 & Research & $\begin{array}{l}\text { Construction } \\
\text { economics }\end{array}$ & Professor & $<20$ & Architect \\
\hline \#20 & Research & Real estate economics & Professor & $<20$ & $\begin{array}{l}\text { Real estate } \\
\text { economist }\end{array}$ \\
\hline \#21 & Research & Architecture & Professor & $<30$ & Architect \\
\hline
\end{tabular}

n.a.: not available.

\subsection{Understanding of Perceived Risk by Developers}

In this context, it must be mentioned that the risk perception of developers differed significantly from premises in the expected utility theory. From a behavioral point of view, intuitive risk assessments are called "perceived risk" [52]. The individual perceived risk is less an objective feature than a subjective and context-dependent construct, which is determined by cognitive and emotional factors [53-55]. Behavioral knowledge suggests that both quantitative factors, such as the level and the probability of the outcome, as well as qualitative factors and personal characteristics of individuals, e.g., age, gender, and education, influence the level of perceived risk $[53,56]$. The results show that people generally assess risks differently than is predicted when following the premises of the expected utility theory. In accordance with the prospect theory $[57,58]$, the following findings can be summarized for the subjective assessment of probabilities:

- The distorted perception of probabilities by (i) overestimating high probabilities as well as the frequency or probability of rare and desired events, and (ii) underestimating low probabilities as well as the frequency or probability of frequent and undesirable events;

- The reduction in distributions to a few points;

- The preference of verbal probability expressions (strongly context-dependent and imprecise) versus "numerical" probabilities;

- The separate perception of the probability of occurrence and their results; and

- The use of inappropriate and incomplete data to form probability judgments.

Additionally, positive and negative results (profits vs. losses) were separately perceived and assessed. The distinction between profits and losses often depends on context and subject-specific reference points, rather than a fixed zero point. Moreover, individuals tend to ignore possible events or results which are far in the future, or the occurrence of which is regarded as very unlikely [59]. 


\subsection{The Stochastic Valuation Model}

The second stage of the mixed-method approach was the integration of environmental risks in a stochastic valuation that was subsequently applied to a case study: an office building in Germany. The project was modeled from the perspective of a trade-developer who buys the land, develops the building, and sells it after completion. Valuing a stream of risky cash-flows, in the sense of company or project valuation, is one of the most important economic tasks and of particular importance during the preparatory stages of the decision-making process. In this paper, the decision was based on the results of the valuation, combining the expected returns (mean value) of the project with the risks of it (through an appropriate risk measure such as standard deviation or value at risk [60]. This approach allows for the value contribution of the risk management to be explicitly made.

In this paper, we used a risk-profile valuation combined with the certainty equivalent method. An uncertain aggregated cash- flow is modeled through the cumulation of the uncertain cash-flow of each period discounted by risk-free interest rates to the valuation date $(t=0)$. The resulting distribution of the aggregated cash flow (risk profile) is then valued by a one-period certainty equivalent model using the corresponding multi-period risk premium $l_{1, . ., T}$. This valuation method is suitable for projects with finite duration, where payment shifts are common but does not represents operative risks $[61,62]$. Such modeling implies an infinite risk-bearing capacity at any point of time $t$, which corresponds to the view of the interviewed developers, as all projects are backed by the parent company. As a result, the accumulated stochastic discounted value of all cash flows is valued using with a one-period model. The model is based on previous work by Gleißner [63] and Dorfleitner and Gleißner [64]. However, in this paper, the model was developed further and included environmental and long-term risks. Moreover, we used empirical data to describe the risk distribution. Formally we have:

$$
V\left(X_{1}, \ldots, X_{T}\right)=E\left[\sum_{t=1}^{T} \frac{\widetilde{F C F_{t}}}{\left(1+r_{f}\right)^{t}}\right]-R\left[\sum_{t=1}^{T} \frac{\widetilde{F C F_{t}}}{\left(1+r_{f}\right)^{t}}\right] \cdot l_{1, . ., T} \cdot d
$$

$V\left(X_{1}, \ldots, X_{T}\right)=$ Discounted value of all cash flows from period 1 to $\mathrm{T}$

$E[x]=$ expected value of $\mathrm{X}$

$T=$ last period

$t=$ time period in the expected investment process

$\widetilde{F C F_{t}}=$ uncertain net free cash flow generated at time $\mathrm{t}$ (incl. investment costs as negative cash flow)

$r_{f}=$ risk-free interest rate

$R[x]=$ risk measure of $\mathrm{x}$

$l_{1, \ldots, T}=$ multi-period risk price for the time period 1 to $\mathrm{T}$. The term can be interpreted as a risk premium which the investment has to yield for every unit of (centered) risk taken.

$d=$ factor for diversification of an assessment, e.g., diversification of assets in other projects.

It is important to mention that the diversified "typified assessment subject" represents only a portion of the risks of the assessment object: for example, in the model world of the CAPM, the assessment subject is perfectly diversified, so he is influenced only by the systematic risks. With our formula, we allow the valuation from the point of view of an unperfect diversified subject, and take this degree of diversification through the "risk diversification factor" (d) into account [65-67].

In order to be able to correctly weight the measure of risk measure in the evaluation, the risk price $l_{1, \ldots, T}$ must be determined. In doing so, the expected risk premiums and the risk factors on the capital 
markets are compared. The multi-period risk premium is calculated as the difference between the equity cost of the market portfolio at time $\mathrm{t}\left(\widetilde{r m}_{t}\right)$ and the risk-free interest rate $\mathrm{r}_{f}$.

$$
l_{1, . ., T}=\frac{E\left[\prod_{t=1}^{T}\left(1+\widetilde{r m}_{t}\right)-\left(1+r_{f}\right)^{t}\right]}{R\left[\prod_{t=1}^{T}\left(1+\widetilde{r m}_{t}\right)\right]}
$$

In this article, the net free cash flow, $F C F_{t}$, is depicted by an MCS representing the aggregation of the most important risks identified during the interviews. The distribution of the risks as inputs for the MCS is based on real data originating from the real estate experts. This was carried out on the average relevance of the risks of a development project with an expected profit of $10 \%$. As most project managers had no experience in risk quantification, the answers were on the qualitative scale. The interviewees assigned a relevance for each risk between 0 (not relevant) to 10 (very relevant). Since quantitative data are required for the simulation, a conversion based on studies about the psychology of risk perceptions was used. It was assumed that a risk with the highest relevance value 10 would counteract the yield in its worst case by four times, e.g., from the expected $+10 \%$ profit to $-30 \%$ loss. Furthermore, it was assumed that the effect is halved with every further degree of relevance. The effect on the margin (in \%) for any relevance $r$ is thus calculated with the formula: $=\frac{0.4}{2^{(10-r)}}$. In addition to the risks, uncertain inflation was modeled for both scenarios to retrieve a future retail price [68]. The detailed model of the risk calculation is provided in Appendix B.

Part three of the mixed-method approach was the application of the developed model to a case study, similar to Apanavičiene et al. [69], Olsson et al. [70] or Yan et al. [71]. The investigated location is an office building, located in a central area of a medium-sized city in Germany, which covers $1588 \mathrm{~m}^{2}$ and contains seven floors. The main parameters were obtained from an example of an interviewed developer. At this point, it must be mentioned that a trade developer has a different time-frame than a build-and-hold developer that builds and then rents a property and rents the space to earn profits. Our model mainly applies to the former. This point is further developed in the Discussion section.

An office building was used as the commercial market is less fragmented than the housing market, meaning that the results are applicable to a large sample of real estate projects. Additionally, office building projects were forerunners in large-scale building certification and information about environmental impacts have become standard in the planning and investment processes (interviews $\# 2$, \#8, \#9, and \#13).

\section{Results}

In total, 59 risks were identified in the literature. We summarized these to 42 risks, of which five were added by experts during pre-tests (see Appendix A). The final list of risks is based on previous work, e.g., Chan et al. [35], Abdul-Rahman et al. [72], or Adair and Hutchison [73]. Similar to Arja et al. [6], risks are divided into external and internal (project) risks. External risks arise outside of the building's boundaries. They affect the project cost and its life cycle, but typically remain outside the building manager's control. The only way to reduce their influence is to predict them far in advance and/or to design the potential for a building to adapt to possible future changes that may be imposed. Internal or project-related risks correspond to the building's internal environment, which influences the decisions of the building manager.

\subsection{Identified Risks in Literature and Interviews}

In general, customer needs and "wishes" have become more and more important (\#15). For most customers, the materials themselves are not of the utmost importance, with their interests focusing more on design or the environmental certification of projects (\#8,\#15). Other developers argue that the quality of the used material is more important to customers (\#1, \#5). Additionally, safety measures, e.g., fire prevention, have gained importance in recent years (\#5). In general, project developers trust what 
they know (\#15). In order to be applied, HQMs need to be functionally superior (\#1) or they need a marketing case, i.e., regional resources that convince customers or politicians (\#4). Important questions for developers are: "How established are the innovative materials? Do admissions/approvals exist?" as well as "How do the material characteristics influence the use phase?" (\#15). Additionally, most of the risks decrease if the developer is experienced and has professional management and planning, i.e., there is lower risk in contracts with agencies or subcontractors (\#6). The better the planning of a project developer, and the more experience and number of actors who are involved in the early stages, the lower the project-related risks (\#8). Other developers just hand the risk over to contractors (\#5). Finally, sufficient supply of material is important. Developers are very keen on variety within the supply network because monopolistic structures tend to dominate the market and prices (\#3, \#11). Moreover, having more suppliers lowers the risk if one supplier goes bankrupt (\#17).

Table 2 shows the 12 most important risks perceived by the experts. Increasing resource or raw material prices, changes in environmental regulation, and changes in building regulations or standards are the most important risks for conventional materials.

Table 2. Most important risks (based on expert interviews).

\begin{tabular}{ccccc}
\hline No. & Conventional Materials & Index & High Quality Materials & Index \\
\hline 1 & Increasing resource/raw material prices & 5.00 & Litigation & 5.39 \\
2 & Changes in environmental regulations & 4.94 & Increasing resource/raw material prices & 5.33 \\
3 & Changes in building regulations/norms & 4.94 & Inadequate maintenance & 5.17 \\
4 & Economic crisis & 4.83 & Delay/availability of labor & 5.06 \\
5 & Changing political majorities & 4.72 & Economic crisis & 4.89 \\
6 & Disagreement with stakeholder & 4.50 & Historical finds/monument protection & 4.83 \\
7 & High competition in buying parcels & 4.50 & Inaccurate cost estimation & 4.83 \\
8 & Historical finds/monument protection & 4.33 & Changes in building regulations/norms & 4.78 \\
9 & Litigation & 4.33 & Disagreement with stakeholder & 4.78 \\
10 & Inaccurate cost estimation & 3.83 & Changes in environmental regulations & 4.39 \\
11 & Availability of labor & 3.67 & Changing political majorities & 4.33 \\
12 & Inadequate maintenance & 3.44 & High competition in buying parcels & 4.33 \\
\hline
\end{tabular}

In comparison, litigation, increasing resource or raw material prices, and inadequate maintenance are ranked as the most important for HQMs. Some of these risks have a direct financial impact, e.g., increasing resource prices, while others have an indirect effect, e.g., disagreement with stakeholder, and lead to delays in project finalization and thus higher rates in debt capital or financial penalties agreed on in the contract (\#1) or shortfalls in revenue (\#6).

HQMs show overall higher values than conventional materials (see Table 3). The interviewees confirm that, on average, a higher risk for HQMs (31 times, interviewees rated risks in combination with HQM higher). Three times, interviewees rated risks (all in external) in combination with conventional materials higher than with HQMs. Eight times, risks in combination with conventional materials were rated higher than HQMs. While the average score on the risk-index of all conventional risks was 3.05, HQMs show a score of 3.55. Similar scores are visible for the median values at 3.17 and 4.00, respectively, and standard deviations of 1.16 and 1.28. Differences between conventional materials and HQMs as well as differences for HQM between external and project risks were at least significant on a $90 \%$ confidence interval.

For external risks, the dominance of conventional materials over HQMs seem to be less prominent. Overall, $47 \%$ (\#15) of the external risks rate conventional materials with lower scores, while $20 \%$ show the score as equal, and HQMs receive lower scores for $33 \%$ of the risks. Moreover, the differences in average score, median, and standard deviation are lower as well.

In the case of internal risks, conventional materials show lower risks $89 \%$ of the time. Only $11 \%$ of the questioned risks are perceived as lower for HQMs. The results support the tendency that project developers prefer conventional materials, as they expect lower negative impacts on their projects. This 
is mainly because less experience with innovative materials leads to higher risk in project-related aspects (\#4,\#14,\#15).

Table 3. Descriptive results of the interviews (based on expert interviews).

\begin{tabular}{|c|c|c|c|c|c|c|c|c|c|}
\hline & \multicolumn{3}{|c|}{ ER } & \multicolumn{3}{|c|}{ PR } & \multicolumn{3}{|c|}{ Total } \\
\hline $\mathrm{CM}<\mathrm{HQM}$ & \multicolumn{3}{|c|}{$7(47 \%)$} & \multicolumn{3}{|c|}{$24(89 \%)$} & \multicolumn{3}{|c|}{31 (74\%) } \\
\hline $\mathrm{CM}=\mathrm{HQM}$ & \multicolumn{3}{|c|}{$3(20 \%)$} & \multicolumn{3}{|c|}{$0(0 \%)$} & \multicolumn{3}{|c|}{$3(7 \%)$} \\
\hline \multirow[t]{2}{*}{$\mathrm{CM}>\mathrm{HQM}$} & & $5(33 \%)$ & & & $3(11 \%)$ & & & $8(19 \%)$ & \\
\hline & $\mathrm{CM}$ & HQM & Total & $\mathrm{CM}$ & HQM & Total & $\mathrm{CM}$ & HQM & Total \\
\hline Average & 3.03 & 3.78 & 3.41 & 3.09 & 3.14 & 3.11 & 3.05 & 3.55 & 3.30 \\
\hline Median & 3.17 & 4.06 & 3.36 & 3.33 & 3.22 & 3.28 & 3.17 & 4.00 & 3.31 \\
\hline Standard deviation & 0.98 & 1.13 & 1.11 & 1.46 & 1.46 & 1.44 & 1.16 & 1.28 & 1.24 \\
\hline
\end{tabular}

CM: conventional materials; HQM: high quality materials; ER: external risk, PR: project risk.

The following section discusses the individual risks according to their importance for conventional materials. Moreover, the difference in ranking between conventional and HQMs is analyzed (see Table 4 at the end of this section). Difference is defined as the variation between the index ranking of the conventional materials and the index ranking of the high-quality materials. The higher the variation, the larger the differences in the ranking. A difference of $(+3)$ means that the risk is ranked three positions higher, and thus is more important for conventional materials than for HQMs.

Changes in environmental regulations are less important for HQMs than for conventional materials (+13). As mentioned earlier, HQMs are better prepared for stricter environmental regulations, and are therefore less prone to risk regarding maintenance and resale value (\#1, \#7, \#8, \#20). HQMs might also have an advantage regarding changing regulations; due to their selection in association with a specific reason, they fit better to a certain situation (\#4). In general, new environmental legislation, energy efficiency, plays a particularly important role, as it leads to higher investment costs (\#1, \#8). Most of the experts (i.e., \#6) consider efficient technical equipment as an energy efficiency measure. Innovative equipment is more likely to avoid costs than innovative materials, as an exchange is easier in case of a malfunction (\#6). The quality of these machines is becoming more and more important, especially in times of smart metering and high connectivity (\#1, \#5). However, the installation of the equipment is connected to the availability of workers; the more complex the machines, the more difficult it is to find appropriate high-skilled workers (\#17).

Increasing resource and raw material prices is important for both material groups, as evidenced by the fact that it is ranked second for both indices (difference is 0 ). The lower resource use of innovative and green materials could be one reason for that (\#14). Other developers argue that HQMs are only used if they are cheaper or allow faster construction time (\#6). Resource and material prices are a diverse topic due to some materials being a global topic (steel), and others being sourced regionally (gravel) (\#1,\#17). As a result, developers rate topics differently, depending on their main use in a company. Moreover, practitioners order the materials and products far in advance due to the capacity of suppliers, leading to the existence of long-term contracts that are less vulnerable to increasing resource prices (\#4). The selection of materials and suppliers is an important topic in general, as most developers prefer several suppliers that create competition, thereby decreasing material costs (\#6). Developers are seldom faced with the unavailability of materials; a lack of a construction material simply leads to increased prices (\#17).

Economic crisis is a high-ranked risk for both conventional and HQMs, although it seems to be more important for conventional materials (difference +1 ). Its general value is connected to the demand for new real estate projects, the availability of construction companies, and the availability of free cash flows (\#17). Materials are purchased regionally, and prices decrease during economic crises (\#4). This effect is stronger for conventional materials than for HQMs (\#6, \#14). Contrastingly, developers want to differentiate themselves from the masses and gain a competitive advantage (\#4), which can be achieved by HQMs, as they create unique selling points for projects and attract clients and investors 
(\#11,\#13). Others say, however, that during economic crises, people concentrate on what they know, and hence they stick to conventional materials (\#6).

Although not as significant, a similar difference $(+4)$ can be observed for changes in building regulations and standards. This risk is not equal for all developers and all phases during construction. First, it can be reduced if developers are in frequent contact with regulatory bodies; good communication between all stakeholders can lower the risk substantially (\#5). Second, it depends on which part of the project is influenced by the new regulation. Moreover, the type of regulation change is relevant. On-site approvals count from the day of inspection, while changing standards are applicable until the day of project finalization. Therefore, standards are much riskier for developers as they can influence already-existing parts of the project (\#3). HQMs not only seem less vulnerable to environmental standards, but also to building standards in general. However, some experts see HQMs as more vulnerable to changing regulations due to a lack of experience $(\# 4, \# 6)$ or additional safety margins (\#14). Bureaucratic hurdles are higher for HQMs, which can have a negative effect on the cash flow as implementation takes longer. On the other hand, missing or unspecific regulations are beneficial for a developer as there is more leeway to design and shape a project (\#6). Changes in building regulations, as with changes in the tax system, also have indirect consequences, as the administrative body within a company needs to adapt to these changes, and new documentation becomes necessary. This results in additional costs and delays in project finalization (\#3, \#17).

Political majorities are an important issue as they might result in delays to, or even the cancelation of a project (\#1). In our ranking, conventional materials seem more vulnerable to changing political majorities (+10). Different political viewpoints seem to have a higher influence on real estate projects built with conventional materials. One reason for this could be that green and innovative materials have a higher acceptance in public perception, and thus these projects have a higher probability in finalization, regardless of changes to political majorities. In general, the risk resulting from changing majorities is lower if a plan exists and the planning is concluded $(\# 6, \# 15)$ since this signifies that development has reached a later stage (\#5). The longer the project takes until finalization, the higher the risk of changes being deemed necessary due to changing political majorities (\#3, \#8). Moreover, there are indirect risks because, e.g., very few decisions are made shortly before and after an election, which increases the risk of delay in project finalization (\#17). Finally, some experts even argue that the lack of experience with HQMs might lead to the cancelation of projects, e.g., because certification or EPDs are missing (\#8).

Disagreement with stakeholder ranks sixth for conventional materials and ninth for HQMs (+3). Some experts (\#3; \#4,\#6) see no difference, as stakeholders often disagree with the entire project rather than individual material groups. On the other hand, the lower risk for HQMs can be explained by the higher enthusiasm for HQMs. Even so, unforeseen complications, such as vapors, may lead to disagreements with stakeholders (\#14). The main impact of a disagreement is a delay in project finalization and thus a later selling date (\#8). Additionally, stakeholders might make special requests, like special windows or noise control, which leads to higher costs (\#1). In general, stakeholder issues are an up-and-coming topic and are becoming increasingly important (\#17), not only during construction, e.g., noise of the construction site, but also because of concerns regarding the entire project (\#6). Stakeholders are a highly unpredictable risk if not addressed in advance (\#5). Buildings and projects must blend in with their surroundings in order to reduce the risk of disagreement with stakeholders (\#4).

Competition of buying parcels is currently a high risk in real estate development. Similarly to the risk of stakeholder disagreement, competition in buying land is a risk at a very early stage of project management. Some experts argue that HQMs might help when acquiring property as HQMs allow for new and innovative buildings (\#1), while others argue that vendors just want to see the money (\#16). In general, this is currently a high risk as parcels in most developed countries are rare and a lot of investors and developers are looking for new possibilities (\#5). If competition of buying parcels leads to delays in project finalization, HQMs might have an advantage, as construction times can be 
shortened due to innovative processes, i.e., faster drying of concrete (\#14). With a difference of +9 , the greater importance for conventional materials is clear.

Historical finds or monument protection is the first risk that is ranked higher for HQMs (difference -2). One reason for this might be the strict guidelines in material use for these projects (\#5, \#9, \#14) and missing empirical values for HQMs (\#8). However, there is also the possibility of new materials allowing for easier refurbishment of a building, e.g., interior insulation (\#8, \#9, \#11), or strict regulations acting as an argument for HQMs and against cheaper conventional materials (\#13). In general, historical finds are always a high risk for developers, as during the building and refurbishment processes new information might come to light (\#1).

Litigation is ranked number 1 for HQMs and number $9(-8)$ for conventional materials. This can mainly be explained by the lack of experience with new materials and the connected high chance of litigation resulting from misuse, wrong installation, or unforeseen maintenance procedures (\#4, $\# 5$, \#6, \#10,\#11, \#14). The topic has recently become more important (\#3,\#14,\#17) and most of the developers already include a budget for litigation in their project planning (\#5). One reason for this growing importance is the complexity of current projects, which often leads to jurisdictional issues (\#5). Apart from the design, projects become more complex as more materials are applied, e.g., cements or glues, which is always problematic due to mistakes potentially being associated with the variety of input variables. In particular, if several subcontractors have to work together, cooperation is crucial, and the risk of mistakes increases (\#3). The risk of delays due to complexity mainly depends on if the application of HQMs increases or decreases complexity (\#14). Finally, missing precedents for HQMs foster the fear of lengthy litigation processes (\#14).

Experience in the application of different materials also plays a role in cost estimation. Inaccuracy is ranked 10th for conventional materials and seventh for HQMs (-3). Often, innovative products are planned individually for every project, leading to higher costs being connected to these materials (\#2). In addition, more effort and precision are applied to HQMs, as managers and engineers try to minimize risk with new and more expensive materials (\#4,\#13). In contrast, there is less tolerance in manufacturing HQMs, as precision is important, and thus more volatility in cost estimation occurs (\#14). Moreover, HQMs have the general disadvantage that processes and linkages between stakeholders within the construction process are not so well attuned and, thus, the risk of delays for these materials is higher (\#8,\#11,\#14). Bad or insufficient internal management increases costs due to delays or faulty construction (\#17). In general, delays due to wrong cost estimations or miscalculations of working hours are a result of external institutions, e.g., administration or politics (\#5), and, hence, not always an indicator of internal imprecision. Finally, in some cases, realistic cost estimations might lead to losing the mandate for a project and, thus, lower turnover (\#17). Therefore, while not all companies aim to estimate costs realistically in a first step, in the view of a sophisticated risk management strategy, this is irresponsible and endangers the survival of the entire company.

A large difference can also be observed in the availability of labor (-9). This is a general problem during boom periods for the entire construction industry $(\# 5, \# 8, \# 12, \# 18)$, but this issue is a high risk in particular for HQMs (rank 4). Obviously, it is more difficult to acquire the highly skilled labor necessary to apply complex HQMs, as most of these materials are rather new, and less suppliers are available on the market (\#4, \#5,\#11).

The largest difference in ranking $(-13)$ can be seen for inadequate maintenance. As with the cost estimations, less information is available for new materials (\#8,\#11). Consequently, maintenance measures are ranked third for HQMs. For conventional materials, it is known which techniques can be applied to certain problems; for HQMs, this experience is missing (\#4). The risk for HQMs can be lowered if projects are certified according to environmental standards, e.g., LEED, because life cycle thinking and end-of-life play an important role in certification and thus provide indicators regarding maintenance (\#8). Customers want economic solutions for maintenance, and most of the time this is provided by conventional materials (\#5). 
Table 4. Differences between materials (based on expert interviews).

\begin{tabular}{ccccc}
\hline Risk & Type & Ranking CM & Ranking HQM & Difference * $^{*}$ \\
\hline Changes in environmental regulations & ER & 1 & 14 & +13 \\
Changing political majorities & ER & 5 & 15 & +10 \\
High competition in buying parcels & PR & 7 & 16 & +9 \\
Changes in building regulations/norms & ER & 4 & 8 & +4 \\
Disagreement with stakeholder & PR & 6 & 9 & +3 \\
Economic crisis & ER & 3 & 4 & +1 \\
Increasing resource/raw material prices & PR & 2 & 2 & 0 \\
Historical finds/monument protection & ER & 8 & 6 & -2 \\
Inaccurate cost estimation & PR & 10 & 1 & -3 \\
Litigation & PR & 9 & 5 & -8 \\
Availability of labor & PR & 14 & 3 & -9 \\
Inadequate maintenance & PR & 16 & & -13 \\
\hline
\end{tabular}

${ }^{*}$ Difference is the variation between the index ranking of the conventional materials and the index ranking of the high-quality materials. The higher the variation is, the larger the differences in the ranking. Both rankings are based on the answers of the interviewees. CM: conventional materials, HQM: high quality materials, ER: external risk, PR: project risk.

For some developers, however, importance is not only allocated to the investment costs, but also to the intensity of construction and manufacturing, as well as the complexity of the installation (\#15). HQMs are complex systems with expensive maintenance, and are prone to failure (\#3).

Meanwhile, the relation of all risk is $36 \%$ to $64 \%$ regarding external risks (ER) and, for project risks (PR), the percentage rises to $42 \%$ and $58 \%$, respectively, for the most important risks. Consequently, external risks are overrepresented in the most important risks.

\subsection{Application of the Identified Risks and the Model in a Case Study}

In the following section, the identified and ranked risks are applied to the cash flow calculation of a commercial real estate object in a medium-sized German city (see Table 5). An office building was used as the commercial market is less fragmented than the housing market and thus the results are applicable to a large sample of real estate projects. Additionally, office building projects were forerunners in large-scale building certification and information about environmental impacts have become standard in the planning and investment processes (\#2, \#8, \#9, \#13). An illustrative risk-free project plan calculation was used as a starting point. The calculated risk costs were therefore not recorded explicitly. These arise automatically in the stochastic model through the effect of asymmetrical risks. Both the rental price and the multiplier are interpreted as given by the market for an analogous (finished) object today and redefined within the simulation. Furthermore, it was assumed that the boundary costs of a conventional construction are not substantially different from those of the innovative construction methods (e.g., the use of trucks, cranes, etc.).

Differences in costs are displayed in different risks. As an alternative investment is needed for comparison and the exemplary development project is based in Germany, a portfolio based on the German stock market, with $7 \%$ expected return and $17.5 \%$ standard deviation, is used at a risk-free interest rate of $2 \%$ and a project term of $\mathrm{T}=4$ periods. These values are used to portray the valuation method. The market values represent the possibility of an alternative investment for the valuation subject. All these market parameters are exemplary and based on the values of the German stock market and of the target of the European Central Bank (ECB), but are to be reassessed in a real case valuation and can differ from these values because of many different reasons. 
Table 5. Cost estimation of the exemplary project (in thousands of euros).

\begin{tabular}{cc}
\hline Purchase of land & 10,000 \\
Derelict land reclamation & 130 \\
Construction costs & 11,185 \\
Ancillary construction costs & 1119 \\
Costs for project management & 976 \\
Financial costs & 1165 \\
Marketing and PR costs & 112 \\
Total costs & 24,686 \\
Rental price & $14.4\left(\right.$ euros $\left./ \mathrm{m}^{2}\right)$ \\
Multiplier & 20 \\
Sales price & 27,456 \\
Profit & $2770(11.22 \%)$ \\
\hline Source: Project plan provided by (\#12) and backed by [74-76].
\end{tabular}

This results in a multi-period risk of 0.5 . The diversification factor is assumed to be 0.5 , since the company, as an assessment entity, does not have only one project, but fluctuations of individual projects are partly offset by each other. The cost parameters are based on a standard developer calculation and cost components were discussed with practitioners. The detailed model of the risk calculation is provided in Appendix B. Table 6 presents the main results of the case study.

While the results show that conventional real estate projects tend to have slightly higher valuation results than projects with HQM, the overall variability (standard deviation in euros) is approximately the same for both types of projects (see Table 6). Based on these findings, the following valuation results of the explained project can be determined: conventional at 1,070,827 euros, HQM at 789,905 euros.

Table 6. Main results of the stochastic model for cash-flow (in euros).

\begin{tabular}{cccc}
\hline Item & CM & HQM & Better Performance \\
\hline Average & $1,540,457$ & $1,270,538$ & $\mathrm{CM}$ \\
Standard deviation & $1,878,521$ & $1,922,531$ & $\mathrm{CM}$ \\
Coefficient of variation & $121.9 \%$ & $151.3 \%$ & $\mathrm{CM}$ \\
99\% Quantile & $-2,211,530$ & $-2,596,502$ & $\mathrm{CM}$ \\
95\% Quantile & $-1,261,177$ & $-1,598,216$ & $\mathrm{CM}$ \\
99\% Deviation-Value-at-Risk & $3,751,986$ & $3,867,040$ & similar \\
95\% Deviation-Value-at-Risk & $2,801,634$ & $2,868,754$ & similar \\
[99\%-1\%] & {$[-2,211,530-6,659,881]$} & {$[-2,596,502-6,464,053]$} & similar \\
[95\%-5\%] & {$[-1,261,177-4,995,583]$} & {$[-1,598,216-4,783,768]$} & similar \\
\hline
\end{tabular}

CM: conventional materials; HQM: high quality materials.

The following graph (Figure 2) shows the density and distribution function of the cash flows for conventional (red shaded area) and HQM (blue shaded area) real estate projects and thus visualizes the results. As the peak of the red area (conventional projects) is more to the right, the probability that these projects gain a higher cash flow is larger. The blue area (HQM projects) is more to the left and, thus, the probability of higher cash flows for these projects is slightly lower than for conventional projects. However, the similar shape of the two areas shows that the uncertainties connected to the cash flows are similar. 


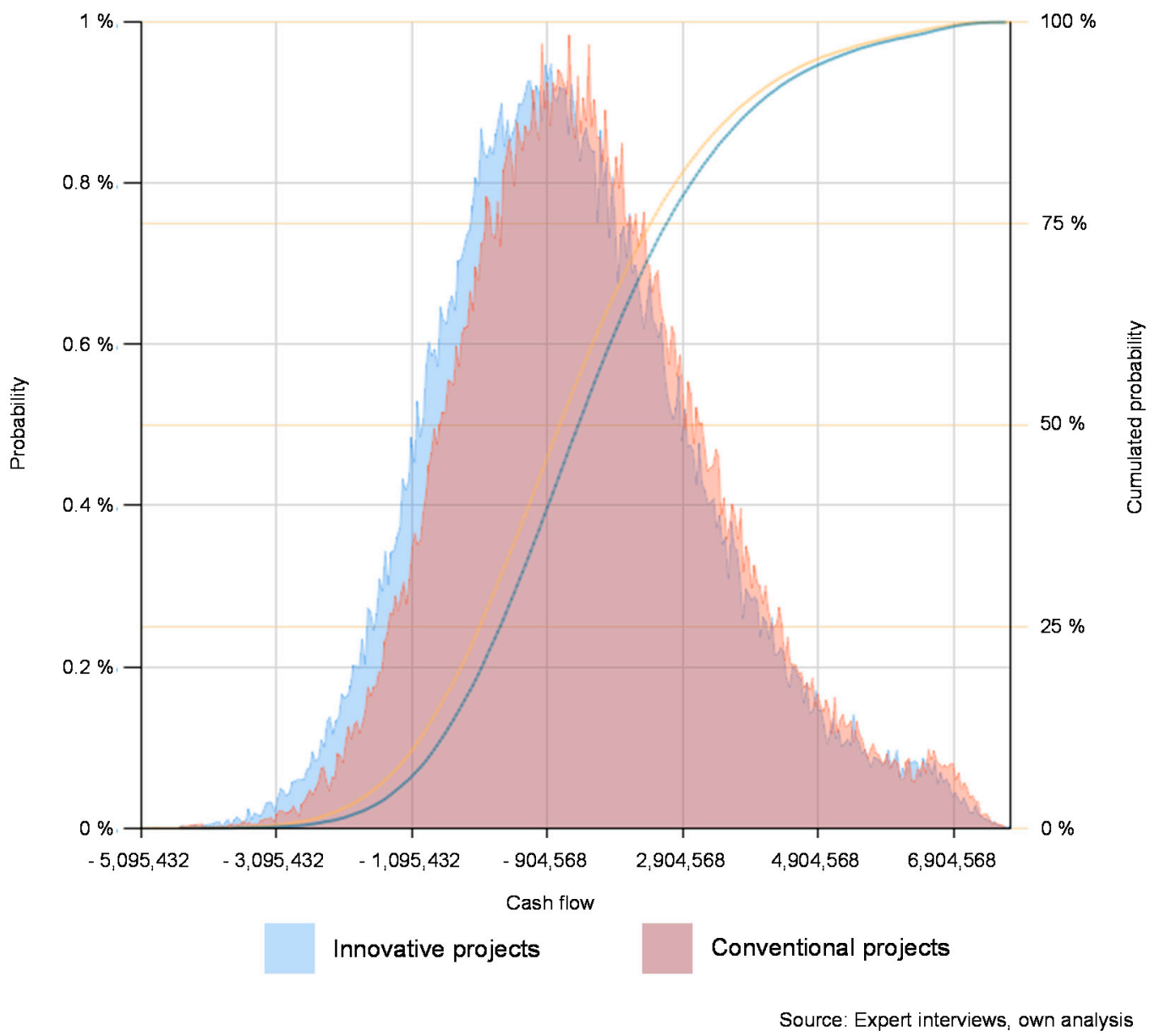

Figure 2. Density and distribution function of the risk profile for real estate projects.

\section{Discussion}

While the use of HQMs is usually financially valued by customers, sustainability itself is only a minor aspect in this context (\#2, \#21) [77]. Clients have been known to show only a light interest in innovative materials, either because they do not care what is beyond the surface of a wall (homeowners) (\#21), they just want a certificate for office space that they intend to rent out (investors) (\#17), or because their own clients are interested in green production processes (companies) (\#16) [78]. In the case of conventional materials leading to a lower margin, developers still prefer them in many situations, as the perceived risk regarding their application is lower (\#2).

Project risks are increasing in association with the current long-term boom in the real estate market of most Western countries, as a high demand for construction companies leads to time-pressure for these companies, resulting in the selection of lower-quality companies that otherwise would not have been chosen (\#8,\#11) [79]. Moreover, in more competitive markets and periods, it is not very likely that companies will try new materials, as the general market pressure is too high (\#8, \#11,\#13). At the same time, cost estimation becomes uncertain, as prices and costs for subcontractors have a high volatility. It becomes even more difficult for developers to plan and estimate new projects (\#5), as poor calculation of work hours reinforces the arduous search for qualified staff and as a result, bad planning can have a dangerous impact on the finalization of a project or increase costs (\#6). Resource prices also vary over time and economic situations; while demand may currently be high resource prices are not a significant issue (\#5). However, this might change in a few years, depending on global economic development. In contrast, the purchase of land is a very hot topic now (\#6) $[80,81]$, with limited availability of unoccupied land meaning that economic risks play an important role when 
selecting potential sites (\#5). In times of accommodative monetary policies and low interest rates, the risk related to inflation is negligible (\#6). It is only for very long projects, where selling prices and financial planning differ, that inflation could pose a problem (\#3).

Although financing is currently not considered a problem, this could change substantially in times of crisis, with the solvency of developers being an important point that gains in significance during times of crisis (\#5). If financing is planned today without considering changing conditions due to financial crises, projects may be canceled (\#1,\#6) [82]. While big developers that are backed by large companies use equity capital and are not overly reluctant regarding changes in financing conditions, this is a major issue for smaller developers (\#5). At the same time, although flexibility in usage, e.g., the change between housing, offices, or hotels, is currently not a big issue due to high demand (\#6), the prominence of the topic is growing, and is key during economic downturns (\#5) [83,84].

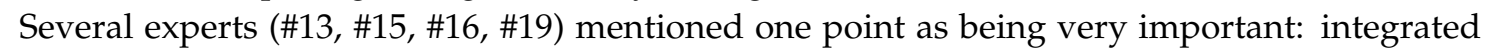
planning. If architects, planners, and different actors that are part of the project do not work together, project risks are tremendous, and profits tend to be zero. However, if integrated planning is established and lived by all stakeholders, project risks are close to zero $[85,86]$. Nevertheless, external risks are still present.

Finally, decent risk management is important, regardless of the economic situation [87]. During boom phases, it helps to avoid projects where tenders are too high, as the overall risk for the company exceeds healthy levels, potentially endangering the entire company (\#11, \#17). During crisis, a sophisticated risk assessment is important to mitigate the requirements for external capital becoming much more stringent, and banks requesting risk controlling measures.

Although conventional real estate projects seem to have positive effects regarding profit and uncertainty, several aspects must be discussed, as they are not displayed in this simplified model. First, innovative materials might allow faster application and drying times, thereby accelerating the entire construction process (\#9). As a result, the sale is concluded earlier, which increases both the value and profit. Second, HQMs might allow thinner construction, meaning more floor space is possible for the same building layout. This would be directly visible in a higher sales price and thus higher value. Moreover, innovative materials allow for new designs and new ways of thinking, thus adding additional value to a real estate object. Third, HQMs might be more expensive in the initial investment; however, lower utility costs can be used in the sales process to increase prices. Fourth, materials that exceed current standards might be interesting for long-term investors, as they benefit from these characteristics in a future sale if regulations become stricter. Future scenarios range from a totally unsellable property of unsustainable real estate, to rental problems, to negative effects on rental and sales prices. Finally, HQMs might attract more attention from developers during economic crises, as materials become cheaper and sustainability is used by developers to attract clients and, thus, as a sales argument.

\section{Conclusions}

The article proposes a risk assessment method that is applied to a case study. Risks are first identified in the literature and subsequently assessed and ranked in importance by practitioners. A stochastic model which extends current methodology due to its inclusion of environmental and long-term risks is then presented. This model is applied to a conventional real estate project and a green project using high quality materials (HQMs). The aim of the article is, first, to show the influence of risk and uncertainty related to real estate projects in cash flow calculations, and second, to present a risk assessment methodology that integrates these risks, and thus accounts for new material properties.

We are well aware that uncertainties and risk assessment associated to real estate market demand an in-depth analysis beyond environmental issues and high-quality materials. However, based on the scope of our research, the results show that-using the risk assumption of the interview partners-increasing resource or raw material prices, changes in environmental regulation, and changes in building regulations or standards are the most important risks for conventional real estate 
projects. Moreover, HQMs do not generate higher cash flows in comparison to the use of cheap materials, and uncertainties in the cash flow prediction are lower for conventional materials.

The results further show that, for a basic stochastic model, the use of conventional materials still outperforms the application of HQMs. In some areas, however, HQMs appear to dominate and suppress existing materials. To strengthen this development, more planners and architects must be convinced of the advantages of HQMs, as they have the highest influence on material selection (\#11, \#21). Another crucial aspect is the sufficient supply of HQMs; developers prefer variety in the supply network because monopolistic structures tend to dominate the market and prices (\#3, \#11).

The analysis is based on the risk perception of the project developers, and not on statistical analysis of actual events. It is known from other studies [55] that risk perception can be distorted. Although this analysis does not necessarily show that innovative construction economically unjustifiable, a decision by project developers against this type of construction is part of their current risk-bearing rationale.

Taking a critical look at our results, risks are contingent on the specific context [88] and, as risk was accumulated during a long-term boom phase in the real estate market, the value of our literature review and the follow-up interviews might be perceived as being too narrow. Risks are volatile and will change over time, especially during an economic crisis [89]. The change in risk distribution is non-proportional and, consequently, a long-term survey is needed to gain a better understanding of risks over time. Moreover, the results are more appropriate for trade developers than for build-and-hold developers, as their time frames differ.

From a practitioner's perspective, the practicability of such a time-consuming risk identification process might be brought into question. For both researchers and practitioners, other methods such as multi-criteria decision-making [90] or the analytic hierarchy process [44] may be appropriate for the straightforward identification of context-specific risks in a project setting [91], as an extensive literature review and interviews might not be possible in a real-world project.

Several aspects might influence the stochastic model, and thus our results. First, as previously mentioned, the identified risks show a high granularity, and most of them are difficult to display in a model (\#17). Second, several risks were evaluated differently; depending on the individual business situation, risk-like changes in tax regulation are perceived as very high (\#3), and others evaluate the risk as lower (\#16). Third, follow-up management and corruption are not part of the official developer calculation, although they have significant influence on project bidding and management in the construction industry [26]. Both factors influence the profitability of a project, which can only be displayed by a far more complex stochastic model.

We recommend verifying the risk perceptions of the participants described here using historical data. Furthermore, the sample of the analysis should be enlarged in order to identify more rigorous differences between the risks for residential construction, commercial buildings, and hotels. We also endorse applying the stochastic model to more cases built with conventional materials and HQMs to verify our results. Additionally, the influence of other gatekeepers that shape the circumstances, such as the political system, insurance companies, or mortgage companies, e.g., Fannie Mae and Freddie Mac, should be investigated.

Author Contributions: Conceptualization was done by all authors. P.B. conducted the literature review and analyzed the interviews and prepared the data for the exemplary calculation. E.K. and P.B. discussed the design of the stochastic model. E.K. implemented the stochastic model. All authors have read and agreed to the published version of the manuscript.

Funding: Open Access Funding by the Publication Fund of the TU Dresden.

Conflicts of Interest: The authors declare no conflict of interest. 


\section{Appendix A}

Table A1. An overview of all risks and the score of each individual risk.

\begin{tabular}{|c|c|c|c|c|}
\hline & \multicolumn{2}{|c|}{ Conventional Material } & \multicolumn{2}{|c|}{ High Quality Material } \\
\hline & Risk Index & Standard Deviation & Risk Index & Standard Deviation \\
\hline \multicolumn{5}{|l|}{ EXTERNAL RISKS } \\
\hline \multicolumn{5}{|l|}{ Customer risks } \\
\hline $\begin{array}{l}\text { Changes in demand } \\
\text { Environmental risks }\end{array}$ & 3.67 & 2.89 & 4.17 & 3.07 \\
\hline Force Majeure (Acts of God) & 1.94 & 1.65 & 2.06 & 2.05 \\
\hline Weather phenomena & 2.33 & 1.53 & 2.67 & 2.25 \\
\hline \multicolumn{5}{|l|}{ Economic risks } \\
\hline Economic crisis & 4.94 & 2.32 & 5.11 & 2.31 \\
\hline Inflation & 1.72 & 2.33 & 1.78 & 2.70 \\
\hline Exchange rate & 1.28 & 2.35 & 1.17 & 2.75 \\
\hline \multicolumn{5}{|l|}{ Social and cultural risks } \\
\hline $\begin{array}{l}\text { Historical finds/monument protection } \\
\text { Political risks }\end{array}$ & 4.33 & 2.71 & 4.83 & 3.02 \\
\hline Missing/unspecific regulation & 3.33 & 2.62 & 4.00 & 2.97 \\
\hline Delay in approval & 1.94 & 2.35 & 1.94 & 2.49 \\
\hline Corruption & 1.83 & 2.34 & 1.83 & 2.48 \\
\hline Labor strikes & 0.83 & 1.13 & 0.83 & 1.13 \\
\hline Changing political majorities & 4.72 & 2.73 & 4.33 & 2.74 \\
\hline \multicolumn{5}{|l|}{ Legal risks } \\
\hline Changes in taxation & 3.56 & 2.85 & 3.22 & 2.83 \\
\hline Changes in environmental regulations & 5.00 & 1.80 & 4.39 & 1.88 \\
\hline Changes in building regulations/standards & 4.83 & 1.77 & 4.78 & 1.94 \\
\hline
\end{tabular}

\section{PROJECT RISKS}

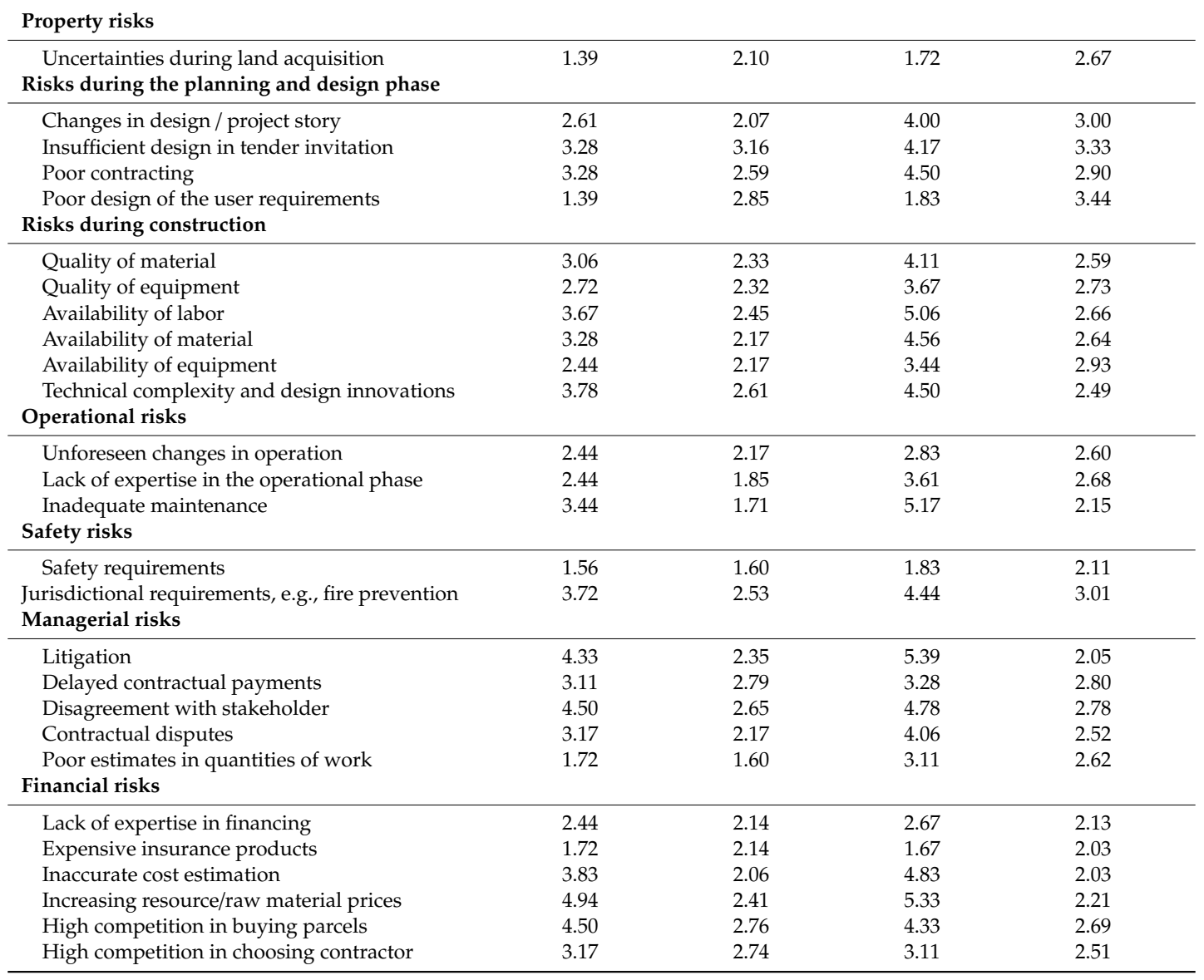




\section{Appendix B}

\section{Appendix B.1 Modeling of the Risks}

Table A2 shows how the risks influence the cost parameter. The risk historical finds/monument protection is not part of the stochastic model as its main influence is on the refurbishment of existing buildings. Most of the ranked risks have a direct impact on the construction costs, while others, e.g., changes in the environmental regulation, also influence the ancillary costs and lower the sales price.

Table A2. Influence of the identified risks on cost parameter.

\begin{tabular}{|c|c|c|c|}
\hline \multirow[b]{2}{*}{ Risk } & \multicolumn{3}{|c|}{ Has an Influence on ... } \\
\hline & 1 & 2 & 3 \\
\hline Increasing resource/raw material prices & Construction cost & & \\
\hline Changes in building regulations/norms & Construction cost & Ancillary construction costs & \\
\hline Economic crisis & Construction cost (lower) & Sales price (lower) & \\
\hline Changing political majorities & Construction cost & Ancillary construction costs & \\
\hline High competition in buying parcels & Cost of land & & \\
\hline Litigation & Ancillary construction costs & & \\
\hline Inadequate maintenance & Sales price & & \\
\hline Availability of labor & Construction cost & & \\
\hline Inaccurate cost estimation & Construction cost & Ancillary construction costs & \\
\hline
\end{tabular}

The risks were either modeled as a relative deviation from planned values with a stochastic mean-reverting process (MR process) and normally-distributed uncertainty or described as separate impacts resulting from an absolute deviation from the planned values described by a triangle distribution. In addition, some risks were modeled as opportunities (positive for the project developer) and threats (negative for the project developer). Other risks just resulted in threats for the developer. Table A3 shows the modeling types used and the details of the model. The uncertainty of increasing resource/raw material prices $\left(\widetilde{\mathrm{Crm}_{t}}\right)$ is described individually. It was split into (uncertain) inflation $\left(\widetilde{i_{t}}\right)$ and inherent variations of resource prices at time $t, \widetilde{\left(\operatorname{Cerm}_{t}\right)}$, deviating from inflation.

$$
\widetilde{\mathrm{Crm}_{t}}=\left(1+\widetilde{i_{t}}\right) \cdot\left(1+\widetilde{\mathrm{Cerm}_{t}}\right)-1
$$

Table A3. Description of the MR process (MR factor $=0.166)$.

\begin{tabular}{|c|c|c|c|c|}
\hline \multirow{2}{*}{ Risk } & \multirow{2}{*}{ Modeled as } & \multirow{2}{*}{ Character } & \multicolumn{2}{|c|}{ Standard Deviation in \% } \\
\hline & & & $\mathrm{CM}$ & HQM \\
\hline Inflation & MR process & $\begin{array}{c}\text { symmetric } \\
\text { opportunity/threat }\end{array}$ & & \\
\hline Increasing resource/raw material prices & MR process & $\begin{array}{c}\text { symmetric } \\
\text { opportunity/threat }\end{array}$ & 0.40 & 0.40 \\
\hline Changes in environmental regulations & MR process & asymmetric threat & 3.00 & 3.93 \\
\hline Changes in building regulations/norms & MR process & asymmetric threat & 4.00 & 2.62 \\
\hline Economic crisis & MR process & $\begin{array}{c}\text { symmetric } \\
\text { opportunity/threat }\end{array}$ & 3.50 & 3.37 \\
\hline Changing political majorities & MR process & asymmetric threat & 3.00 & 3.37 \\
\hline Disagreement with stakeholder & MR process & asymmetric threat & 3.00 & 2.29 \\
\hline High competition in buying parcels & triangular & asymmetric threat & 2.50 & 3.03 \\
\hline Litigation & triangular & asymmetric threat & 2.00 & 1.78 \\
\hline Inadequate maintenance & MR process & asymmetric threat & 1.50 & 3.12 \\
\hline Availability of labor & MR process & asymmetric threat & 1.50 & 4.95 \\
\hline Inaccurate cost estimation & MR process & $\begin{array}{c}\text { symmetric } \\
\text { opportunity/threat }\end{array}$ & & \\
\hline
\end{tabular}


Figure A1 presents three examples of the development and range of risks, including inflation, as an example for an MR process where starting and target values differ; changes in environmental regulation, as an example for an asymmetric threat; and inaccurate cost estimation, as an example for systemic risks.

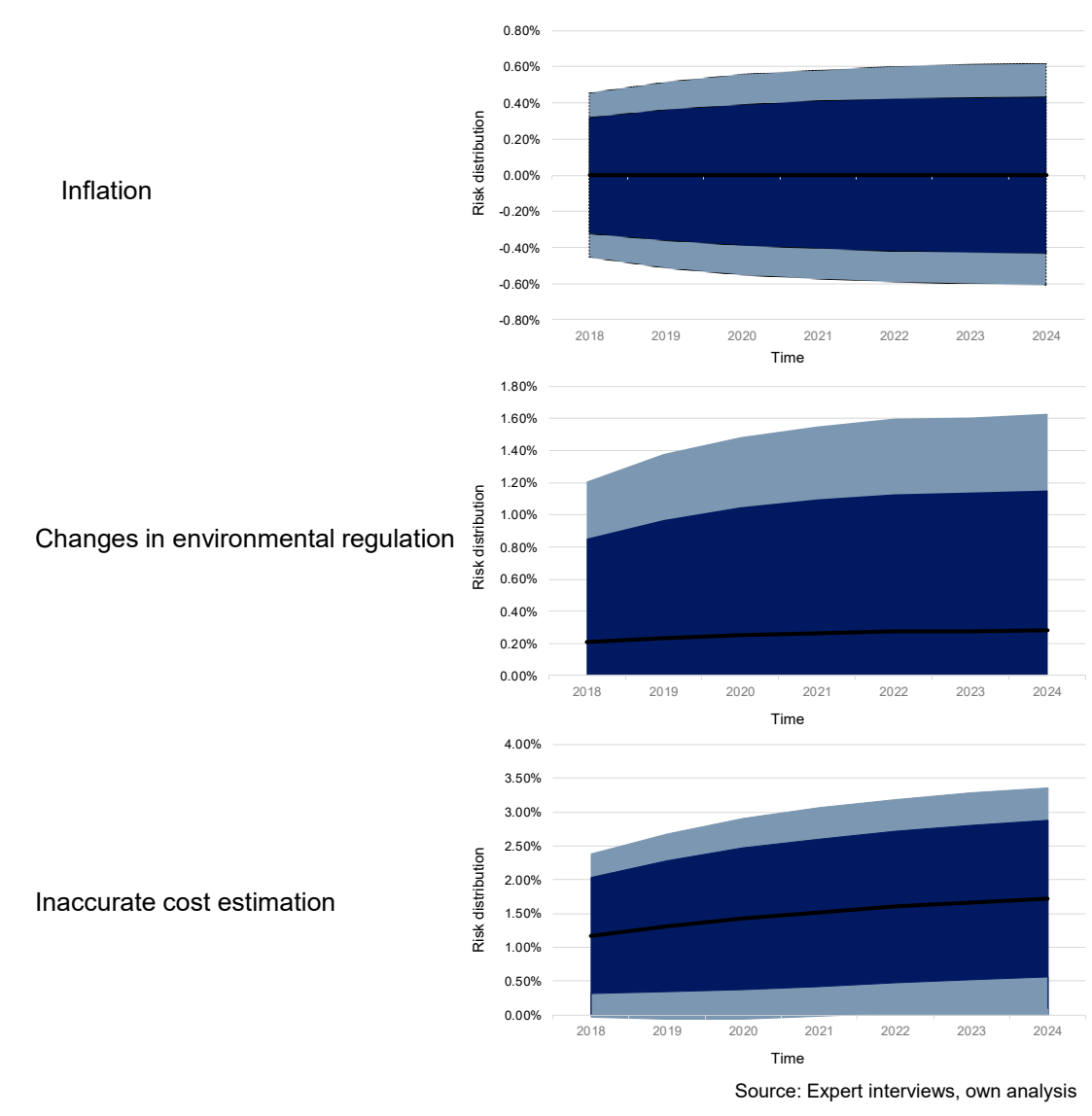

Figure A1. Examples of the development and range of different risks.

Appendix B.2 Modeling the Impacted Costs

The effect of several risks modeled as an MR process and thus as a relative deviation were multiplicatively linked. The difference between the construction costs $\left(R C C_{t}\right)$ and the ancillary construction costs $\left(R A C_{t}\right)$ are:

$$
\begin{gathered}
\widetilde{\operatorname{RCC}_{t}}=\left(1-\widetilde{\operatorname{Rr}_{T}}\right) \cdot\left(1-\widetilde{\operatorname{Rer}_{T}}\right) \cdot\left(1+\widetilde{\operatorname{Rbr}_{T}}\right) \cdot\left(1-\widetilde{\operatorname{Rec}_{T}}\right) \cdot\left(1-\widetilde{\operatorname{Rst}_{T}}\right) \cdot\left(1+\widetilde{\operatorname{Rwf}_{T}}\right) \cdot\left(1-\widetilde{\operatorname{Rco}_{T}}\right) \cdot\left(1+\widetilde{\operatorname{Rpm}_{T}}\right)-1 \\
\widetilde{R A C_{t}}=\left(1-\widetilde{\operatorname{Rer}_{T}}\right) \cdot\left(1+\widetilde{\operatorname{Rbr}_{T}}\right) \cdot\left(1-\widetilde{\operatorname{Rst}_{T}}\right) \cdot\left(1+\widetilde{\operatorname{Rpm}_{T}}\right)-1
\end{gathered}
$$

where $\left(\widetilde{\operatorname{Rre}_{T}}\right)$ : Increasing resource/raw material prices, $\left(\widetilde{\operatorname{Rer}_{T}}\right)$ : Changes in environmental regulations, $\left(\widetilde{\operatorname{Rbr}_{T}}\right)$ : Changes in building regulations/norms, $\left(\widetilde{\operatorname{Rec}_{T}}\right)$ : Economic crisis,

$\left(\widetilde{R s t_{T}}\right)$ : Disagreement with stakeholder, $\left(\widetilde{R w f_{T}}\right)$ : Availability of labor, $\left(\widetilde{R c o_{T}}\right)$ : Inaccurate cost estimation, $\left(\widetilde{R p m_{T}}\right)$ : Changing political majorities

The risks modeled as absolute deviations $(\widetilde{R l} i)$ are added after the relative deviations are applied. Thus, the value of this position in a simulation run is obtained by:

$$
\widetilde{A C_{t}}=A C_{t}^{\text {Plan }} \cdot \widetilde{R A C_{t}}+\widetilde{R l i}
$$


Appendix B.3 Modeling the Sales Price

The stochastic sales price at time $\left(\widetilde{P_{T}}\right)$ is determined as a product of the estimated rental price at time $\mathrm{T}\left(\widetilde{\text { rent }_{T}}\right)$ and the uncertain sales multiplier at time $\mathrm{T}\left(\widetilde{m_{T}}\right)$.

$$
\widetilde{P_{T}}=\widetilde{\text { rent }_{T}} \cdot \widetilde{m_{T}}
$$

Inflation influences both the achievable rental price and the sales multiplier. The uncertain rental price at time $\mathrm{T}\left(\widetilde{\text { rent }_{T}}\right)$ is based on the estimate of today's rental price (rent $\left.{ }_{0}\right)$ of 14.3 euros per $\mathrm{m}^{2}$ and month plus an uncertain inflation development until the end of the project.

$$
\widetilde{\text { rent }}_{T}=\text { rent }_{0} \cdot \text { area } \cdot \prod_{t=1}^{T}\left(1+\widetilde{i_{t}}\right)
$$

The scientific basis behind a sales multiple is that the multiple mathematically displaying the reciprocal of the discounting factor-generally known as property interest rate. A risk-free discount rate is based on the risk-free interest rate, and a risk premium as a function of the overall risk-bearing capacity of the valuation object. In this model, the risk premium was split into a general risk premium $\left(r_{z}\right)$ as well as a premium depending on the modeled uncertainties. Thus, the multiplier $\left(\widetilde{m_{T}}\right)$ is calculated as the reciprocal of the uncertain inflation plus the effects of economic crisis $\left(\operatorname{Rec}_{T}\right)$, changes in environmental regulations $\left(\widetilde{\operatorname{Rer}_{T}}\right)$, and inadequate maintenance $\left(\widetilde{R m_{T}}\right)$, which influence the sales price, as well as a general risk premium $\left(r_{z}\right)$.

$$
\widetilde{m_{T}}=\frac{1}{r_{z}+\left(1+0.5 \cdot \widetilde{i_{T}}\right) \cdot\left(1-0.5 \cdot \widetilde{\operatorname{Rec}_{T}}\right) \cdot\left(1-0.5 \cdot \widetilde{\operatorname{Rer}_{T}}\right) \cdot\left(1+0.5 \cdot \widetilde{\operatorname{Rm}_{T}}\right)-1}
$$

\section{References}

1. Fregonara, E.; Giordano, R.; Rolando, D.; Tulliani, J.M. Integrating Environmental and Economic Sustainability in New Building Construction and Retrofits. J. Urban Technol. 2016, 23, 3-28. [CrossRef]

2. Del Giudice, V.; De Paola, P.; Manganelli, B.; Forte, F.; Martellozzo, F.; Murgante, B. The Monetary Valuation of Environmental Externalities through the Analysis of Real Estate Prices. Sustainability 2017, 9, 229. [CrossRef]

3. Lee, A.H.I.; Kang, H.Y.; Hsu, C.F.; Hung, H.C. A green supplier selection model for high-tech industry. Expert Syst. Appl. 2009, 36, 7917-7927. [CrossRef]

4. Fregonara, E.; Giuseppe Ferrando, D.; Pattono, S. Economic-Environmental Sustainability in Building Projects: Introducing Risk and Uncertainty in LCCE and LCCA. Sustainability 2018, 10, 1901. [CrossRef]

5. Panesar, D.K.; Seto, K.E.; Churchill, C.J. Impact of the selection of functional unit on the life cycle assessment of green concrete. Int. J. Life Cycle Assess. 2017, 22, 1969-1986. [CrossRef]

6. Arja, M.; Sauce, G.; Souyri, B. External uncertainty factors and LCC: A case study. Build. Res. Inf. 2009, 37, 325-334. [CrossRef]

7. Guthrie, G. Regulating Infrastructure: The Impact on Risk and Investment. J. Econ. Lit. 2006, 44, 925-972. [CrossRef]

8. Ding, G.K.C. Sustainable construction-The role of environmental assessment tools. J. Environ. Manag. 2008, 86, 451-464. [CrossRef]

9. Giordano, R.; Serra, V.; Tortalla, E.; Valentini, V.; Procedia, C.A. Embodied energy and operational energy assessment in the framework of nearly zero energy building and building energy rating. Energy Procedia 2015, 78, 3204-3209. [CrossRef]

10. Bernardi, E.; Carlucci, S.; Cornaro, C.; Bohne, R.A. An Analysis of the Most Adopted Rating Systems for Assessing the Environmental Impact of Buildings. Sustainability 2017, 9, 1226. [CrossRef]

11. Fregonara, E.; Giordano Id, R.; Ferrando, D.G.; Pattono, S. Economic-Environmental Indicators to Support Investment Decisions: A Focus on the Buildings' End-of-Life Stage. Buildings 2017, 7, 65. [CrossRef]

12. EY Real Estate Trends. 2016. Available online: http://www.ey-trends.de/downloads/RE_Trends_69_Juni_ 2016.pdf (accessed on 3 March 2020). 
13. Wbcsd Sustainability and Enterprise Risk Management: The First Step towards Integration. World Business Council for Sustainable Development. Available online: https:/www.wbcsd.org/Programs/ Redefining-Value/Business-Decision-Making/Assess-and-Manage-Performance/Resources/Sustainabilityand-enterprise-risk-management-The-first-step-towards-integration (accessed on 3 March 2020).

14. Grafakos, S.; Gianoli, A.; Tsatsou, A. Towards the Development of an Integrated Sustainability and Resilience Benefits Assessment Framework of Urban Green Growth Interventions. Sustainability 2016, 8, 461. [CrossRef]

15. Curto, R.; Fregonara, E. Decision tools for investments in the real estate sector with risk and uncertainty elements. Jahrb. Reg. 1999, 19, 55-85.

16. Boussabaine, H.A.; Kirkham, R.J. Whole Life-Cycle Costing Risk and Risk Responses; Blackwell Publishing: Oxford, UK, 2008.

17. Huffman, F.E. Corporate real estate risk management and assessment. J. Corp. Real Estate 2003, 5, 31-41. [CrossRef]

18. Walls, J.; Smith, M.R. Life-Cycle Cost Analysis in Pavement Design; US Department of Transportartion: Washington, DC, USA, 1998.

19. Alfen, H.W.; Riemann, A.; Leidel, K.; Fischer, K.; Daube, D.; Frank-Jungbecker, A.; Gleißner, W.; Wolfrum, M. Lebenszyklusorientiertes Risikomanagement für PPP-Projekte im Öffentlichen Hochbau; Bauhaus-Universität Weimar: Weimar, Germany, 2010.

20. Gleißner, W.; Garrn, R. Projektrating: Fallbeispiel für Investitionen in erneuerbare Energiequellen. Kredit Rat. Prax. 2012, 5, 11-18.

21. Geltner, D.; Miller, N.; Clayton, J.; Eichholtz, P. Commercial Real Estate Analysis and Investments; Thomson South-Western: Mason, OH, USA, 2016.

22. Eichholtz, P.; Kok, N.; Quigley, J. Why Companies Rent Green: CSR and The Role of Real Estate. Acad. Manag. Proc. 2009, 2009, 1-6. [CrossRef]

23. Reichardt, A.; Fuerst, F.; Rottke, N. Sustainable building certification and the rent premium: A panel data approach. J. Real Estate Res. 2012, 34, 99-126.

24. Szumilo, N.; Gantenbein, P.; Gleißner, W.; Wiegelmann, T. Predicting uncertainty: The impact of risk measurement on value of real estate portfolios. J. Prop. Res. 2016, 33, 1-17. [CrossRef]

25. Gluch, P.; Baumann, H. The life cycle costing (LCC) approach: A conceptual discussion of its usefulness for environmental decision-making. Build. Environ. 2004, 39, 571-580. [CrossRef]

26. McKinsey Reinventing Construction: A Route to Higher Productivity. Available online: http://www.mckinsey.com/industries/capital-projects-and-infrastructure/our-insights/reinventing-constructionthrough-a-productivity-revolution?cid=other-eml-alt-mgi-mgi-oth-1702 (accessed on 3 March 2020).

27. D'Alpaos, C.; Canesi, R. Risks assessment in real estate investments in times of global crisis. WSEAS Trans. Bus. Econ. 2014, 11, 369-379.

28. Fregonara, E.; Ferrando, D.G. How to Model Uncertain Service Life and Durability of Components in Life Cycle Cost Analysis Applications? Stoch. Approach Factor Method 2018, 10, 3642.

29. Emblemsvåg, J. Reengineering Capitalism: From Industrial Revolution Towards Sustainable Development; Springer International Publishing: Cham, Switzerland, 2015.

30. Arashpour, M.; Wakefield, R.; Lee, E.; Chan, R.; Hosseini, M.R. Analysis of interacting uncertainties in on-site and off-site activities: Implications for hybrid construction. Int. J. Proj. Manag. 2016, 34, 1393-1402. [CrossRef]

31. Lehtiranta, L. Risk perceptions and approaches in multi-organizations: A research review 2000-2012. Int. J. Proj. Manag. 2014, 32, 640-653. [CrossRef]

32. TEGoVA. The European Valuation Standards, 7th ed.; The European Group of Valuers' Association: Bruxelles, Belgium, 2012.

33. Mao, Y.; Wu, W. Fuzzy real option evaluation of real estate project based on risk analysis. Syst. Eng. Procedia 2011, 1, 228-235. [CrossRef]

34. Bai, L.; Li, Y.; Du, Q.; Xu, Y. A Fuzzy Comprehensive Evaluation Model for Sustainability Risk Evaluation of PPP Projects. Sustainability 2017, 9, 1980. [CrossRef]

35. Chan, D.W.M.; Chan, A.P.C.; Lam, P.T.I.; Yeung, J.F.Y.; Chan, J.H.L. Risk ranking and analysis in target cost contracts: Empirical evidence from the construction industry. Int. J. Proj. Manag. 2011, 29, 751-763. [CrossRef]

36. Huff, A. Designing Research for Publication; Sage Publishing: Thousand Oaks, CA, USA, 2008. 
37. Zavadskas, E.K.; Antucheviciene, J.; Vilutiene, T.; Adeli, H. Sustainable Decision-Making in Civil Engineering, Construction and Building Technology. Sustainability 2018, 10, 14. [CrossRef]

38. Giordano, R.; Montacchini, E.; Tedesco, S.; Perone, A. Living Wall Systems: A technical standard proposal. Energy Procedia 2017, 11, 298-307. [CrossRef]

39. Fregonara, E.; Ferrando, D.G.; Carbonaro, C. Cost-Risk Analysis for Supporting Urban Regeneration Technological Projects. In Values and Functions for Future Cities; Springer: Cham, Switzerland, 2020; pp. 403-423.

40. Ilg, P. How to foster green product innovation in an inert sector. J. Innov. Knowl. 2019, 4, 129-138. [CrossRef]

41. Robinson, S.; Simons, R.; Lee, E.; Kern, A. Demand for green buildings: Office tenants' stated willingness-to-pay for green features. J. Real Estate Res. 2016, 38, 423-452.

42. DODG World Green Building Trends. 2016. Available online: https://www.construction.com/toolkit/reports/ world-green-building (accessed on 3 March 2020).

43. Eichholtz, P.; Kok, N.; Yonder, E. Portfolio greenness and the financial performance of REITs. J. Int. Money Financ. 2012, 31, 1911-1929. [CrossRef]

44. Saaty, T.L. How to Make a Decision: The Analytic Hierarchy Process. Eur. J. Oper. Res. 1990, 48, 9-26. [CrossRef]

45. Chari, A.; Henry, P.B. Risk Sharing and Asset Prices: Evidence from a Natural Experiment. J. Financ. 2004, 59, 1295-1324. [CrossRef]

46. Weber, E.U.; Siebenmorgen, N.; Weber, M. Communicating Asset Risk: How Name Recognition and the Format of Historic Volatility Information Affect Risk Perception and Investment Decisions. Risk Anal. 2005, 25, 597-609. [CrossRef]

47. Manning, C. Managing Environmental Risk and Investment Opportunities to Maximize Shareholder Wealth. J. Real Estate Res. 2009, 7, 351-359.

48. Högberg, L.; Lind, H.; Grange, K. Incentives for Improving Energy Efficiency When Renovating Large-Scale Housing Estates: A Case Study of the Swedish Million Homes Programme. Sustainability 2009, 1, 1349-1365. [CrossRef]

49. Eisenhardt, K.M. Building Theories from Case Study Research. Acad. Manag. Rev. 1989, 14, 532-550. [CrossRef]

50. Sandelowski, M. Focus on Qualitative Methods Sample Size in Qualitative. Res. Nurs. Heal. 1995, 18, $179-183$. [CrossRef]

51. Mayring, P. Qualitative Content Analysis. Forum Qual. Soc. Res. 2000, 1, 159-176.

52. Gleißner, W.; Winter, P. Der Risikomanagementprozess als Problemlösungsprozess: Eine verhaltenswissenschaftliche Perspektive. In Die Rolle des Controllers Im Mittelstand; Lingnau, V., Ed.; Springer: Cham, Switzerland, 2008; pp. 221-244.

53. Jungermann, H.; Slovic, P. Die Psychologie der Kognition und Evaluation von Risiko. In Risiko und Gesellschaft; VS Verlag für Sozialwissenschaften: Wiesbaden, Germany, 1993; pp. 167-207.

54. March, J.G.; Shapira, Z. Managerial Perspectives on Risk and Risk Taking. Manag. Sci. 1987, 33, $1404-1418$. [CrossRef]

55. Pfister, H.R.; Böhm, G. Risikowahrnehmung. Wirtschaftspsychologie 2005, 310-315.

56. MacCrimmon, K.R.; Wehrung, D.A. Characteristics of Risk Taking Executives. Manag. Sci. 1990, 36, 422-435. [CrossRef]

57. Kahneman, D.; Tversky, A. Prospect Theory: An Analysis of Decision Under Risk. In Handbook of the Fundamentals of Financial Decision Making; World Scientific Publishing: Singapore, 2013.

58. Tversky, A.; Kahneman, D. Advances in prospect theory: Cumulative representation of uncertainty. J. Risk Uncertain. 1992, 5, 297-323. [CrossRef]

59. Kunreuther, H.; Ginsberg, R.; Miller, L.; Sagi, P.; Slovic, P. Limited Knowledge and Insurance Protection: Implications for Natural Hazard Policy; National Technical Information Service: Charlotteslville, VA, USA, 1977.

60. Artzner, P.; Delbaen, F.; Eber, J.M.; Heath, D. Coherent measures of risk. Math. Financ. 1999, 9, $203-228$. [CrossRef]

61. Ballwieser, W.; Hachmeister, D. Unternehmensbewertung-Prozess, Methoden und Probleme; Schäffer-Poeschel Verlag Stuttgart: Stuttgart, Germany, 2016. 
62. Shang, K.; Chen, Z. Risk Appetite: Linkage with Strategic Planning. Society of Actuaries, 2012. Available online: https://www.soa.org/globalassets/assets/files/research/projects/research-risk-app-linkreport.pdf (accessed on 11 March 2020).

63. Gleißner, W. Risikoanalyse und Replikation für Unternehmensbewertung und wertorientierte Unternehmenssteuerung. WiSt-Wirtschaftswissenschaftliches Stud. 2011, 40, 345-352. [CrossRef]

64. Dorfleitner, G.; Gleißner, W. Valuing streams of risky cash flows with risk-value models. J. Risk 2016, in press.

65. Petersen, K.; Zwirner, C.; Brösel, G. Handbuch Unternehmensbewertung. Funktionen, Moderne Verfahren, Branchen, Rechnungslegung; Buundesanzeiger: Köln, Germany, 2013.

66. Glaser, J.S. The Capital Asset Pricing Model: Risk Valuation, Judicial Interpretation, and Market Bias. Bus. Lawyer 1995, 50, 687-716.

67. IFRS. Illustrative Examples to Accompany IFRS 13 Fair Value Measurement. 2013. Available online: https://www.ifrs.org/-/media/feature/supporting-implementation/ifrs-13/education-ifrs-13-eng.pdf (accessed on 27 January 2020).

68. Rottenstreich, Y.; Hsee, C.K. Money, kisses, and electric shocks: On the Affective Psychology of Risk. Psychol. Sci. 2001, 12, 185-190. [CrossRef]

69. Apanavičienė, R.; Daugèlienè, A.; Baltramonaitis, T.; Maliene, V.; Rosen, M.A. Sustainability Aspects of Real Estate Development: Lithuanian Case Study of Sports and Entertainment Arenas. Sustainability 2015, 7, 6497-6522. [CrossRef]

70. Olsson, S.; Malmqvist, T.; Glaumann, M. Managing Sustainability Aspects in Renovation Processes: Interview Study and Outline of a Process Model. Sustainability 2015, 7, 6336-6352. [CrossRef]

71. Yang, H.J.; Song, J.; Choi, M.J. Measuring the Externality Effects of Commercial Land Use on Residential Land Value: A Case Study of Seoul. Sustainability 2016, 8, 432. [CrossRef]

72. Abdul-Rahman, H.; Loo, S.C.; Wang, C. Risk identification and mitigation for architectural, engineering, and construction firms operating in the Gulf region. Can. J. Civ. Eng. 2012, 39, 55-71. [CrossRef]

73. Adair, A.; Hutchison, N. The reporting of risk in real estate appraisal property risk scoring. J. Prop. Invest. Financ. 2005, 23, 254-268. [CrossRef]

74. Diederichs, C.J. Immobilienmanagement Im Lebenszyklus-Projektentwicklung, Projektmanagement, Facility Management, Immobilienbewertung; Springer: Berlin/Heidelberg, Germany, 2006.

75. Viering, M.G.; Liebchen, J.H.; Kochendörfer, B. Managementleistungen im Lebenszyklus von Immobilien.; BG Teubner Verlag/GWV Fachverlage GmbH: Wiesbaden, Germany, 2007.

76. Heinrich, N. Entwicklung Von Parametern Zur Risikobewertung Für Projektentwicklungen Auf Brachgefallenen Flächen-Am Beispiel Freizeitlich Orientierter Projekte; Kassel University Press GmbH: Kassel, Germany, 2006.

77. Klein Woolthuis, R.J.A. Sustainable Entrepreneurship in the Dutch Construction Industry. Sustainability 2010, 2, 505-523. [CrossRef]

78. Hermann, R.R.; Wigger, K. Eco-Innovation Drivers in Value-Creating Networks: A Case Study of Ship Retrofitting Services. Sustainability 2017, 9, 733. [CrossRef]

79. Crowe, C.; Dell'Ariccia, G.; Igan, D.; Rabanal, P. How to deal with real estate booms: Lessons from country experiences. J. Financ. Stab. 2013, 9, 300-319. [CrossRef]

80. $\mathrm{Xu}, \mathrm{T}$. The Relationship between Interest Rates, Income, GDP Growth and House Prices. Res. Econ. Manag. 2017, 2, 2470-4407. [CrossRef]

81. Glaeser, E.L. Real estate bubbles and Urban development. Asian Dev. Rev. 2017, 34, 114-151. [CrossRef]

82. Zhu, X.; Lin, S.; Wang, L.; Wu, W.; Qin, Q.; Zhu, X.; Lin, S.; Wang, L.; Wu, W.; Qin, Q. A Study of the Debt of Real Estate-Related Industries; Springer: Singapore, 2018.

83. De Paris, S.R.; Lopes, C.N.L. Housing flexibility problem: Review of recent limitations and solutions. Front. Archit. Res. 2018, 7, 80-91. [CrossRef]

84. Hoendervanger, J.G.; De Been, I.; Van Yperen, N.W.; Mobach, M.P.; Albers, C.J. Flexibility in use: Switching behaviour and satisfaction in activity-based work environments. J. Corp. Real Estate 2016, 18, 48-62. [CrossRef]

85. Godschalk, D.; Malizia, E. Sustainable Development Projects: Integrated Design, Development, and Regulation; Routledge: Abingdon-on-Thames, UK, 2017.

86. Mikaelsson, L.Å.; Larsson, J. Integrated planning for sustainable building production-an evolution over three decades. J. Civ. Eng. Manag. 2017, 23, 319-326. 
87. Battisti, F.; Guarini, M.; Chiovitti, A. The Assessment of Real Estate Initiatives to Be Included in the Socially-Responsible Funds. Sustainability 2017, 9, 973. [CrossRef]

88. Woods, M. A contingency theory perspective on the risk management control system within Birmingham City Council. Manag. Account. Res. 2009, 20, 69-81. [CrossRef]

89. Peni, E.; Smith, S.; Vähämaa, S. Bank corporate governance and real estate lending during the financial crisis. J. Real Estate Res. 2013, 35, 313-343. [CrossRef]

90. Kannan, D.; Khodaverdi, R.; Olfat, L.; Jafarian, A.; Diabat, A. Integrated fuzzy multi criteria decision making method and multiobjective programming approach for supplier selection and order allocation in a green supply chain. J. Clean. Prod. 2013, 47, 355-367. [CrossRef]

91. Baird, I.S.; Thomas, H. Toward a Contingency Model of Strategic Risk Taking. Acad. Manag. Rev. 1985, 10, 230-243. [CrossRef]

(C) 2020 by the authors. Licensee MDPI, Basel, Switzerland. This article is an open access article distributed under the terms and conditions of the Creative Commons Attribution (CC BY) license (http://creativecommons.org/licenses/by/4.0/). 